\title{
Torture: Henri Alleg and the Algerian War
}

\author{
Jeff Erickson
}

During the Algerian War (1954-1962), the French military used torture to gain information and, in turn, suppress the Algerian nationalist movement. Torture had a dehumanizing effect on the individuals of the native population, both suspected nationalist sympathizers and those who performed the torture. This created a sense of unity and humanity among the victims of torture at the hands of the French military. Torture built an "army" against the French military in Algeria. The Question was a memoir of one of the military's victims, Henri Alleg. Alleg was an important member of the Algerian nationalist movement in Algeria and France during the Algerian war. Alleg's memoir contributed to the gathering storm of anti-colonial and anti-torture activists and authors that changed the public's opinion of France's involvement in Algeria. The French military's dehumanizing methods of torture performed on Henri Alleg and the native Algerian population contributed to France's loss of the Algerian War.

Henri Alleg can be seen as many things: Jewish, European, Polish, French, but London born; during his life he lived in France, Algeria and Czechoslovakia. He has been called many things including pig, communist, editor, rat, husband, prize catch, friend and activist. Despite these various distinctions, Alleg considers himself an Algerian and a communist. Born with the last name Salem, he took a last name of Kabyle origin (Berber region in northern Algeria) while working within the underground during World War II. ${ }^{1}$ Alleg's experiences after arriving in Algeria in 1939 shaped him as a person,

1 Donald Reid, "The Question of Henri Alleg," The International History Review, 29, no. 3 (2007), 576 .

Colloquium for History Majors (World): France and Algeria at War, 16W:051. Instructor: Dr. Mériam Belli, Spring 2013, The University of Iowa 
activist and communist. These experiences contributed to his involvement with the Algerian nationalist movement.

Under Vichy control, Alleg's activities in Algiers during World War II marked the beginning of his non-institutional education as a communist and anti-colonial activist. Living in an Algiers hostel exposed him to many members of the oppressed native Algerian population. As Alleg stated in his book The Algerian Memoirs, "What I learnt from them about the humiliations, insults and racial discrimination to which they had been subjected in their short lifetimes taught me more about the real situation of the Algerians under colonial rule and their aspirations than I could ever have learnt from the most scholarly university courses."2 Alleg witnessed first-hand the dehumanizing treatment of the native Algerian people during the Vichy and French occupation of Algeria. Speaking of the French military's attitude on the use of torture on Algerians, Alleg wrote, "After all it was the only way to deal with Arabs." 3 His calling, as an Algerian independence activist, was solidified because of these experiences under Vichy occupation and continued after the war.

Henri Alleg continued his anti-colonial activism after World War Two. Alleg found a home in the PCA, Parti Communiste Algerien. The PCA was the Algerian communist party until legally disbanded in 1955 by French authorities. ${ }^{4}$ The French government banned the PCA for its involvement with Algerian independence activities. Within the PCA, Alleg continued his fight for an independent Algeria. Disseminating communist pro-independence propaganda throughout Algeria, appealing to the Algerian public was Alleg's weapon of choice. Through his involvement with the PCA, his reputation for advocating Algerian independence and his communist writing, Alleg became the editor of the daily publication the Alger republicain in 1951.

Under Alleg, the Alger republicain was intended to cast a wide net, reaching the Algerian public in its entirety. Although widely considered a communist publication, Alleg maintained, "It was understood that Alger republicain was not and must not be a party organ but would rather be the paper of the whole spectrum of anti-colonialists, regardless of origin, religion or political

2 Henri Alleg, The Algerian Memoirs, translated by Gila Walker (London: Seagull, 2012), 41.

3 Alleg, Memoirs, 171.

4 Irwin Wall, "The French Communists and the Algerian War," Journal of Contemporary History, 12, no. 3 (1977), 526. 
affiliation." 5 This daily was meant for all types of people, from the welleducated intellectual to the uneducated laborer. ${ }^{6}$ The Alger republicain appealed to and informed the native population about the nationalist movement.

With the onset of the conflict between France and the Algerian nationalist movement after All Saints Day in 1954 the French government had begun to pay more attention to the Alger republicain and Henri Alleg. The French authorities in Algeria censored much of the Alger republicain's content, seized its equipment and arrested its staff members. In place of the articles censored by the French government, Alleg printed, "Alger republicain speaks the truth and nothing but the truth but cannot say the whole truth."7 In September 1955, the French government in Algeria banned the PCA and the Alger republicain because of its involvement with "rebel" insurrection. Henri Alleg's anti-colonial and anti-torture fight went from being a large public thorn in France's side to an underground battle. Even after the "official" banning of the Alger republicain, Alleg and others continued to covertly create and distribute this publication. It had gained him some notoriety within the pro-French Algeria government, military and local police. He was a "prize catch" to his French torturers after his arrest. ${ }^{8}$

Alleg's memoir describing the torture he experienced at the hands of French paratroopers was published and distributed in France and around the world in 1958, at the height of the Algerian War. Henri Alleg, while in hiding from the French military in Algeria, went to his friend Maurice Audin's home. Alleg was unaware that a French detective had arrested Audin the previous day and was waiting in Audin's home. The detective took Alleg into custody and transported him to El Biar. The Question was Henri Alleg's memoir of his experiences at the hands of the torturous French paratroopers. The memoir was written in 1957 shortly after his month-long confinement and torture for being a nationalist sympathizer and an anti-torture advocate. After its release early in 1958, the French government quickly banned the book in France. A month after its ban, the two most read books in France were The Question and Anne Frank's diary. ${ }^{9}$ This controversy surrounding The Question only increased its popularity around the world. Alleg's memoir was a best seller in the United

5 Alleg, Memoirs, 159.

6 Alleg, Memoirs, 159.

7 Alleg, Memoirs, 172.

8 Henri Alleg, The Question, trans. John Calder (Lincoln: University of Nebraska Press, 2006), 40.

9 Reid, “Question of Henri Alleg," 574. 
States in 1958. ${ }^{10}$ The Question details Alleg's dehumanizing experiences of electrocutions, beatings, water boarding, burning, and water deprivation along with being drugged all dealt by the French paratroopers in the Centre de Tri (El Biar). Alleg not only experienced torture first hand, he also witnessed the same inhumane treatment of the native Algerian population.

The French paratroopers attacked the victim on two fronts, physically and mentally. The location of the torture site was important to the victim's psychological torture. The El Biar detention center, as described in The Question, was a nondescript, unfinished apartment building. The physical state and location of the building was meant to create a sense of fear and isolation while asserting the French military's control. The French military purposefully chose this location because they believed its location to be important to the torture process. The military intended an individual under arrest to feel ignored, invisible, forgotten. Alleg wrote that during one of his "sessions" a paratrooper mentioned that they were three floors underground so his screams could not be heard. ${ }^{11}$ As Kate Millett, a feminist activist and author, explained, "The character of clandestine detention, the practice of bringing victims to undisclosed locations, is central to torture- both to its secret and illegal character and to its terror and force. One is in limbo, one disappears." 12 The location was intended to demonstrate the French military's God-like power over Alleg's finite existence within his torturer's grasp.

The French paratroopers used dehumanizing terms to identify Alleg and others during their detainment and torture. Henri Alleg mentions throughout The Question that his captors rarely referred to him using his name. This lack of proper humanistic identification protected the conscience of the ones performing the torture. Not referring to someone as an individual, with a name, created a separation of human qualities from the victim for the torturer. Alleg's torturers referred to him in this way throughout The Question. The torturers called Alleg 'pig,' 'customer,' 'rat' and 'prize catch' among other nonhumanistic names. As Marnia Lazreg, a professor of sociology and researcher at City University of New York, explained, "The prisoner is but a vessel through which the torturer works." ${ }^{13}$ The French paratrooper removed the

10 Reid, "Question of Henri Alleg," 574.

11 Alleg, Question, 55.

12 Kate Millett, The Politics of Cruelty (New York: W.W. Norton \& Co, 1994), 81.

13 Marnia Lazreg, Torture and the Twilight of Empire: From Algiers to Baghdad (Princeton: Princeton University Press, 2008), 133. 
human part of Alleg and recreated him as nothing more than an object to work through. The French military frequently referred to Alleg and the Algerian people as bougnouls, an ethnic slur meaning "rats," loosely translated. In the 1984 film The Algerian War, General Bollardiere commented on the French dehumanization of the Algerian people, "It's easy to torture a bougnoul, because you figure he's not a human being." 14

The French military used these dehumanizing identifications to break down the prisoner's sense of self. Alleg's captors used these identifications to establish their superiority and reinforce the belief of his inferiority. The French paratroopers repeatedly addressed Alleg and other native Algerians using the familiar and demeaning form of "you," $t u .{ }^{15}$ Alleg insisted that his torturers not use the demeaning form $t u$ to address him, which was met with laughter by the paratroopers. ${ }^{16}$ These terms were not uniquely used in referring to Alleg. The paratroopers often used dehumanizing terms when communicating with other "Arab" prisoners. Alleg made it a point to include in his memoir the connection his French wardens made between himself and the other "rats" or "Arabs." A French paratrooper exclaimed "Well, a Frenchman! He's sided with the rats against us? You'll take care of him, won't you, Lo-!"17 The paratrooper took away Alleg's French identity and transformed him into the enemy, siding with the "rats." That statement not only dehumanized Alleg, but also discredited and dehumanized the native Algerians involved in the nationalist movement.

The French military repeated the theme of "everybody talks" to Alleg and other suspected nationalist sympathizers inside and outside the French detention centers. The paratroopers claimed that they would find a way to make everybody talk. This claim was intended to instill a sense of helplessness in Alleg and others, making it difficult to withstand torture. Outside the walls of the detention centers, the French military placed posters meant to sway the native population from supporting the members of the nationalist movement (see illustrations $1 \& 2$ posted at the end)..$^{18}$ These illustrations also implied that the French military took the information they needed at any cost and that no one could withstand the methods of the French military. These illustrations

14 Tzvetan Todorov, "Torture in the Algerian War," trans. Arthur Denner, South Central Review, 24, no. 1 (2007): 21.

15 Lazreg, Twilight, 133.

16 Alleg, Question, 43.

17 Alleg, Question, 41.

18 Martin Evans, Algeria: France's Undeclared War (Oxford: Oxford University Press, 2012), 136-137. 
discredited the Algerian nationalists or "rebels" by comparing them to a group of criminals, vagrants or barbarians. Notice how the "rebels" were portrayed: angry facial expressions, unclean with tattered clothing. The "rebels" were portrayed as lower forms of the human race that were not to be trusted or helped. These posters gave the impression that the French military always captured the "rebels" and their sympathizers. Talking to the French authorities was inevitable. The French military claimed that everyone talked but Alleg's own experience exposed this claim as propaganda. Despite everything Alleg endured he claimed to never have been broken or to have given up any information.

The French military used various atrocious methods of torture in the many detention centers. Alleg's description of the torture he endured shocked much of the French public. Alleg had first-hand experience of the French military's dehumanizing methods of torture. Alleg recalled at one point, "They unfastened my trousers, took down my underpants and attached the electrodes to each side of my groin. They took turns in manipulating the knob of the magneto..." 19 The attack on male and female genitalia was a common practice within the walls of El Biar and other detention centers. Alleg had electrodes attached to his face, mouth, ears, chest, penis and other areas. Another method the paratroopers used was water torture to simulate drowning and create panic, as life seemed to be slipping away. Alleg's torturers burned him all over his body. He was forced to sleep either on the concrete floor or a mattress filled with barbed wire. The French paratroopers involved in Alleg's torture created a world of pain, discomfort, sleeplessness and what seemed to be imminent death. His torture was intended to push him over the edge and to break his will. The paratroopers attempted to replace Alleg's humanity with pain and humiliation. The French military created certain roles, for themselves and the victims, during the torture process to enhance the dehumanizing effects on the victim.

The French military established distinct roles, differentiating themselves from the prisoners, and aiding in their domination over the tortured. The paratroopers played the role of god over the prisoner. A French paratrooper, after restraining Alleg to a wooden board for his first "session", stood over Alleg to impress upon him that the French paratroopers were superior. Alleg recalls "I saw Lo- standing above me, his legs apart, one foot on each side of the plank at the height of my chest with his hands on his hips in the attitude of

19 Alleg, Question, 55. 
a victor." 20 The French paratrooper defined their roles, superior/torturer to inferior/tortured. Alleg overheard a paratrooper verbally impressing his godlike status over a prisoner, "He shouted at him: 'Say your prayers to me."'21 Creating these roles took away the prisoner's power and sense of self-worth.

The French military also psychologically tortured prisoners by threatening to harm their families. French paratroopers continuously threatened Alleg's family in order to prove the French military's power and Alleg's helplessness. A French paratrooper calmly said to Alleg in response to his refusal to talk “...we'll take your wife. Do you think she'll stand it?" another paratrooper added "Do you think that your children are safe just because they're in France? We'll bring them here whenever we want." 22 This was intended to instill a sense of helplessness in the face of the far superior French military. Psychological torture had a profound impact on Algerian captives as documented in Alleg's memoirs.

Viewing Algerians as a sub-human race made the use of torture more agreeable, if not, enjoyable for the torturer. General Paul Aussaresses, a member of the paratroopers during the Algerian War, referred to FLN members and suspected Algerian nationalist sympathizers as rats, criminals, rebels, militants, and fellaghas (bandits), among other disparaging names. The purpose of using these terms in his memoirs was to create a less than human picture of the Algerian people. In his memoir, General Paul Aussaresses spoke of the "disappearances" of many prisoners during the Algerian War. He explained, "Only rarely were the prisoners we had questioned during the night still alive the next morning. Whether they had talked or not they generally had been neutralized." 23 Humans, freedom fighters, fathers, teachers, sisters don't "disappear," only bougnouls and fellaghas "disappear." This rhetoric concerning native Algerians was common within the ranks of the French military and desensitized the French soldier.

It was common among the French military to treat torture as a form of entertainment and sport. Trivializing torture as a form of sport or entertainment is evidence of the dehumanizing effect that torture had on the torturer. No longer was torture an assault on a human being but a show or a spectacle for the viewing pleasure of the audience. Lazreg noted, "Some

20 Alleg, Question, 41.

21 Alleg, Question, 91.

22 Alleg, Question, 57-58.

23 Aussaresses, Casbah, 127.

http://ir.uiowa.edu/iowa-historical-review 
torturers referred to the serial kicking and punching of their prisoners as 'soccer'. Watching the séance was akin to watching a soccer match. Torture is a sport." 24

Henri Alleg, like many others imprisoned, had himself been the focus of such sport or entertainment. On numerous occasions, paratroopers were the "studio audience" that enjoyed the torture show. While at El Biar, Alleg overheard a paratrooper exclaim that he was excited to see for the first time a prisoner being burned. They referred to this act as "roasting." Torture was a show, something to be excited about witnessing. ${ }^{25}$ Alleg recalled at one point during a session of electrocution that the paratroopers were "all around me sitting on the packing cases. Cha- and his friends emptied bottles of beer." 26 It was common for the torturer and the audience to laugh at, jeer, insult, and taunt the victim. This behavior showed just how desensitized the paratroopers became as a result of the torture process. During the torture sessions the French military created an alternate world. The characters within this world of torture were transformed. The torturer changed himself from a soldier into a deity and the victim became sub-human. The physical act of performing torture on another became a sport with an audience, a source of entertainment.

Henri Alleg authored The Question to show the people of France the dehumanizing methods their government used in the name of France. Alleg felt a responsibility as an Algerian and communist to fight for the independence of the oppressed Algerian people who were being subjected to torture. This responsibility was born of a "brotherhood" he felt with the Algerian people and the communist belief that colonial oppression should be stopped. The paratroopers subjected Henri Alleg to the same treatment as native Algerians in El Biar. Many of the Algerian prisoners embraced Alleg as one of their own. Alleg recalled that while in El Biar, the Algerian prisoners "understood that, like themselves, I had been tortured and they greeted me in the passage: 'Have courage, brother!' In their eyes I read a solidarity, a friendship, and such complete trust that I felt proud, particularly because I was a European, to be among them." 27

The "disappearance" of his friend Maurice Audin, along with many others, was another motivation for writing The Question. The French military had the

24 Lazreg, Twilight, 134.

25 Alleg, Question, 50.

26 Alleg, Question, 45.

27 Alleg, Question, 92. 
propensity to make certain trouble makers "disappear." Audin was a French mathematics professor at an Algerian university, a communist and an Algerian nationalist sympathizer. The paratroopers at El Biar brought Alleg and Audin together momentarily. All that Audin said to Alleg was, "It's hard, Henri." 28 Audin was quickly taken away and soon after he "disappeared," just as many others had before him. While incarcerated at the Lodi detention center, after his time in El Biar, Alleg's lawyer Matarasso, spoke with him about the importance of publishing his experiences. Matarasso said, "You'll be writing for the thousands of Algerians who cannot do so and who have been subjected, or risk being subjected, to the trials that you went through." 29 Alleg wrote his memoirs in part for his friend Maurice Audin.

Soon after the publishing of The Question, French intellectuals formed the Comite Audin to initially look into the "disappearance" of Audin. The French government officially claimed that Maurice Audin was on the run. ${ }^{30}$ Eventually, the Comite Audin took on the task of investigating the use of torture and other human rights violations during the French Algerian War. ${ }^{31}$ The Question and the Comite Audin were two forces within the metropole that helped to force the French public to take issue with the use of torture in Algeria. Audin's disappearance and Alleg's torture was for many people in France horrifying accounts of the French authorities human rights violations during the colonial war. The account exposed "the lies of the leaders who claimed to be defending civilization, democracy and human rights..." 32 While the issue of torture was creating a storm with the French public, it was building an army in Algeria.

The torture and detainment of native Algerians increased unity among them and support for the resistance against the French military. These methods incited the Algerian public to act against their French oppressors. ${ }^{33}$ The French military threw a wide net to capture and suppress the nationalist movement during this battle and throughout the Algerian War. In 1958, Edward Behr, author of The Algerian Problem, wrote "between thirty and forty per cent of the entire male population of the Casbah were arrested at some point..." during

28 Alleg, Question, 46.

29 Alleg, Memoirs, 221.

30 Alleg, Memoirs, 243.

31 Todd Shepard, The Invention of Decolonization (Ithaca: Cornell University Press, 2006), 66.

32 Alleg, Memoirs, 242.

33 Evans, Undeclared, 224-225. 
the battle of Algiers. ${ }^{34}$ Consequently, the mass detainments created support for the independence movement. Albert Camus, a popular French intellectual at the time, declared that torture may have saved some lives by preventing eventual attacks against the French, but "at the same time it has created fifty new terrorists..." 35 The oppression of these arrests brought many of the native population previously not involved in the conflict to the front lines against the French military. The French military's mass arrests and detainment of the Algerian natives concentrated a diverse population of prisoners in one place, including a large number of political prisoners. The political prisoners disseminated pro-independence ideals within the prison creating support for the movement. While detained, Alleg recognized the impact these new ideas had on the prison population. He stated in his memoir, "It had come to the point that the non-political inmates, now very much in the minority, whom the prison administration used as employees, strove to measure up to the political prisoners. They even took risks to do what the clandestine organization in the prison asked of them." 36

Henri Alleg witnessed this growing unity among the native population during executions of Algerian prisoners. Alleg recalled "the entire prison joined together in a single chant...nearly the whole Casbah district- the mothers, wives and sisters- stood on the terraces and chanted in unison, accompanying the condemned man or men (sometimes two or three were taken at once) until the blade of the guillotine fell." 37 The French military's use of torture and other dehumanizing oppressive tactics during the Algerian War built an army for their Algerian enemy, the nationalist movement. Despite the French military's use of torture increasing the native Algerian support of the FLN and the national movement, many members within the ranks of the French military believed it to be a necessity to keep Algeria French.

Torture had been a part of recent French history. The Gestapo's use of torture during World War Two was still fresh in the memories of many within the French military's ranks. Many of these French military figures were involved in the resistance while others were supporters of the Vichy government put in place by the Germans. Many French military officials had been tortured during the war. Not long later after the defeat of Germany, the

34 Alistair Horne, A Savage War of Peace (New York: The Viking Press, 1978), 199.

35 Horne, Savage, 205.

36 Alleg, Memoirs, 217.

37 Alleg, Memoirs, 216. 
French military was using torture to keep Indo-China a colony. Coming off an embarrassing defeat in Indo-China, the French government and military vowed not to lose another colony. ${ }^{38}$ Many of the French military leaders arrived in Algeria within weeks of the defeat in Indo-China. The military brought the practice of torture with them to the Algerian War. Though not all French military members condoned or conducted torture, many within their ranks did. Those who did support the use of torture justified their actions in the name of French national interests, raison d'Etat. ${ }^{39}$

The French military believed that in order to win the war in Algeria, torture was an indispensable tool. Some French military authorities, including Gen. Massu of the French $10^{\text {th }}$ paratrooper division and Gen. Aussaresses of the French Action Service, claimed that the Battle of Algiers could not have been won without the use of torture. The Battle of Algiers (1956-57) was a major battle between occupying French forces and members of the Algerian nationalist movement (specifically the FLN). The outcome of the Battle of Algiers was very damaging to the nationalist movement, especially the FLN and its leadership. Torture may have aided the French victory in the Battle of Algiers, but its use contributed to the loss of the Algerian War. Paul Teitgen, prefect of Algiers during the conflict, commented on the paratroopers' use of torture during the Battle of Algiers, "All right, Massu won the Battle of Algiers; but that meant losing the war." 40 The use of torture created enemies against the French military and led to their ultimate defeat.

In 2001, French General Paul Aussaresses published his memoirs called The Battle of the Casbah. Aussaresses fought in World War Two, Indo-China and Algeria. While in Algeria from 1955-1957, Aussaresses was a member of the French Action Service, under orders to "liquidate all FLN leaders by any means available..." 41 In his memoir, the General never apologized for his part in the use of torture and summary executions. The French military concealed the practice of torture. Torture was never officially authorized but it was unofficially encouraged. As Aussaresses commented in his memoir, "Torture,

38 James D. Le Sueur, "Torture and the Decolonization of French Algeria," Colonial and Post-Colonial Incarceration, edited by Graeme Harper, (London: Continuum International publishing, 2002), 163.

39 Shepard, Invention, 66.

40 Horne, Savage, 207.

41 Paul Aussaresses, The Battle of the Casbah, trans. by Robert L. Miller (New York: Enigma Books, 2006), 28. 
it was tolerated if not actually recommended." He continued, "We didn't discuss it among officers..."42

In 1956, the French Parliament passed the Special Powers Act. The Act "endowed the French military with police authority and virtually unrestricted power to bring an end to the rebellion in Algeria." 43 It gave men like Aussaresses the legal and military backing to conduct torture sessions without specifically and officially condoning its use. In the name of a French Algeria, the native Algerians had become no more than bougnouls to the French government and military.

The French government viewed torture as a growing problem. The French authorities attempted to cover up the news of the dehumanizing methods being used in Algeria. The French public became more opposed to the war in Algeria as the news of torture spread. French military commonly made certain suspects or prisoners "disappear." Members of the French military adhered to the principle, "no body, no crime," in an attempt to cover up torture and other dehumanizing acts. Alistair Horne, a historian of France, wrote of these "disappearances" of Algerian nationalist suspects that "The number of such 'disappearances' may never be verified; the distinguished secretary-general at the Algiers prefecture, Paul Teitgen, put it at just over 3,000" it was "a mass covering-up within the army." ${ }^{4}$ Torture in Algeria was not covered up for long.

The French government censored certain publications in order to cover up the use of torture in Algeria, but keeping the issue of torture out of the public eye failed. Authors and activists like Henri Alleg, Gisele Halimi, Simone de Beauvoir, Jean Paul Sartre, Frantz Fanon and others sparked the torture controversy in France. These influential individuals were educated and well known in their fields of expertise. They authored publications and spoke out protesting the French military's use of torture in Algeria. The Question, by Henri Alleg with a preface by Jean Paul Sartre, was one of these outspoken publications. As previously discussed, the French government quickly banned The Question after its release, but not before 65,000 copies had already been sold. ${ }^{45}$ Alleg stated that The Question "contributed indirectly to bringing together hundreds of university professors and intellectuals around the Audin

42 Aussaresses, Casbah, 129.

43 Le Sueur, "Torture and the Decolonization," 164.

44 Horne, Savage, 202.

45 Reid, "Question of Henri Alleg," 574. 
committee... all of whom worked relentlessly to break the silence imposed by the torturers and killers and their high-placed accomplices." 46 These intellectuals protested against the French government's ban of The Question and demanded a complete report of the French military's use of torture in Algeria. ${ }^{47}$

The Question was the first person account of the torture of a Frenchman, Alleg. Its shocking and vivid first-hand account was especially powerful because the victim was of French origin. Alleg's text reached a wide audience that brought attention to the French military's inhumane practices in Algeria. Jean Paul Sartre, France's most popular intellectual, authored the preface that brought the use of torture to the eyes of the world. Sartre wrote, "Torture is neither civilian nor military, nor is it specifically French: it is a plague infecting our whole era." ${ }^{48}$ One cannot ignore the influence this book had on the French public and world.

Public opinion of the war in Algeria changed as the new of the French government "unofficial" support of the military's use of torture. Simone de Beauvoir, a French intellectual and activist, in a 1960 article in Le Monde, charged the French public to take action against the use of torture that was excused by the French government. She exclaimed, "When the government of a country allows crimes to be committed in its name, every citizen thereby becomes a member of a collectively criminal nation." 49 Accounts of the French military's use of torture, like The Question, reached the French public and had a damaging effect on the war effort. Looking back, many in the French public were ashamed of the use of torture during the Algerian War. In fact, many in the public believed that France "had to wash her hands of the sale guerre [dirty war]." 50

The eight-year Algerian War came to an end in 1962. Algeria became an independent nation with de Gaulle's Fifth Republic passing the Evian Accords. In a strange and awful way, the French military's use of torture contributed to the independence of Algeria. Torture dehumanized the native Algerian population, while at the same time, created unity among them. Torture helped

46 Alleg, Memoirs, 224.

47 Alleg, Memoirs, 224.

48 Horne, Savage, 196.

49 Simone de Beauvoir and Gisele Halimi, Djamila Boupacha: The Story of the Torture of a Young Algerian Girl which Shocked Liberal French Opinion, trans. by Peter Green (New York: Macmillan, 1962), 197.

50 Horne, Savage, 206-207. 
build an "army" for the nationalist cause. The publication of The Question and other publications like it changed the public's opinion of the French involvement in Algeria. Many French military members viewed torture as an acceptable and necessary method of warfare. The French military members who tortured in the name of France will never be brought to justice for their actions in Algeria. The Evian Accords granted amnesty to all involved in military actions in the Algerian War. The Accords provided amnesty in order to encourage people to forget the atrocities in Algeria and to repair the French Republic's reputation as a just society. Those who experienced torture will never forget the inhumanity. Those who tortured will remember that their actions ultimately contributed to their defeat. 


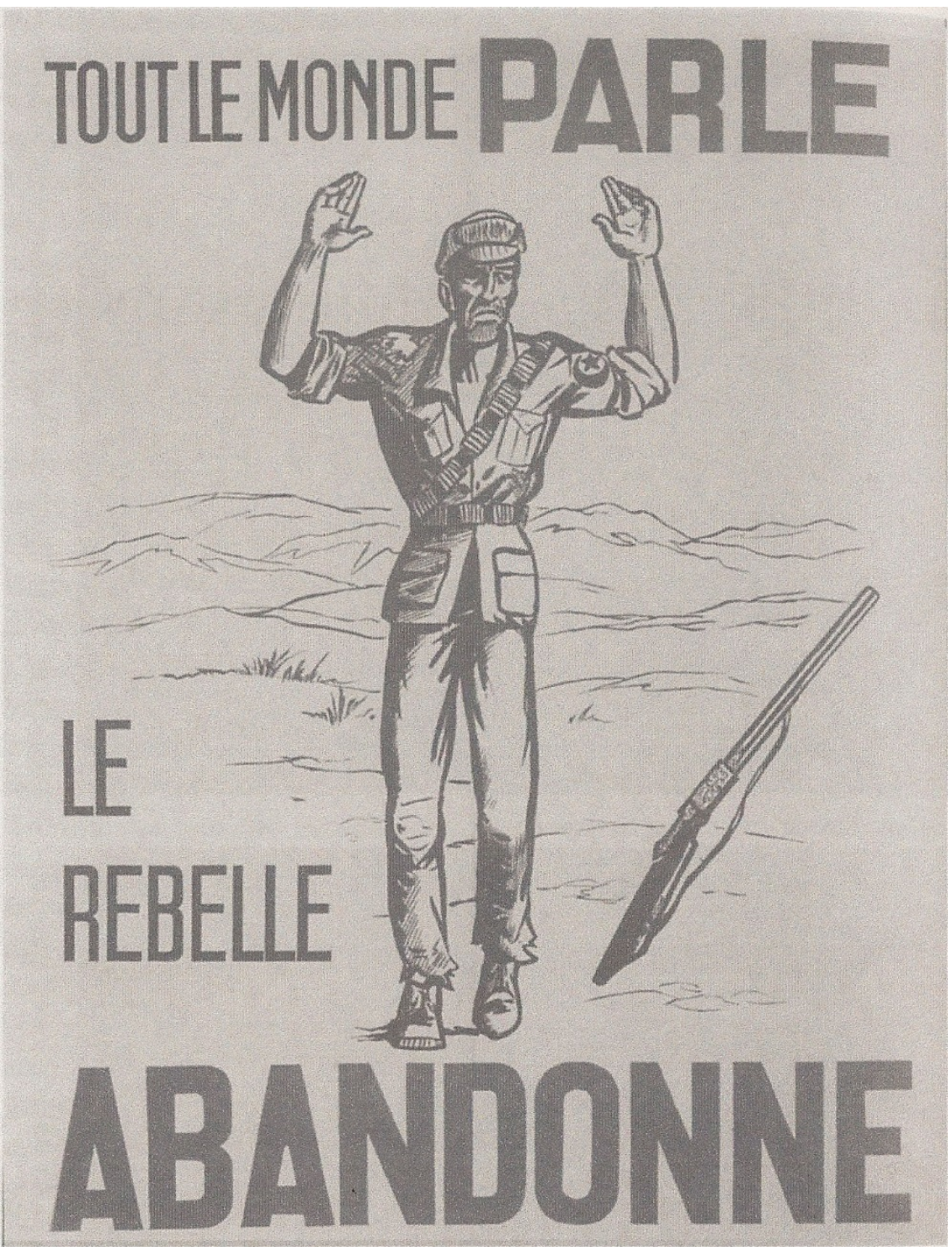

'Everybody Talks - the rebel surrenders'. 


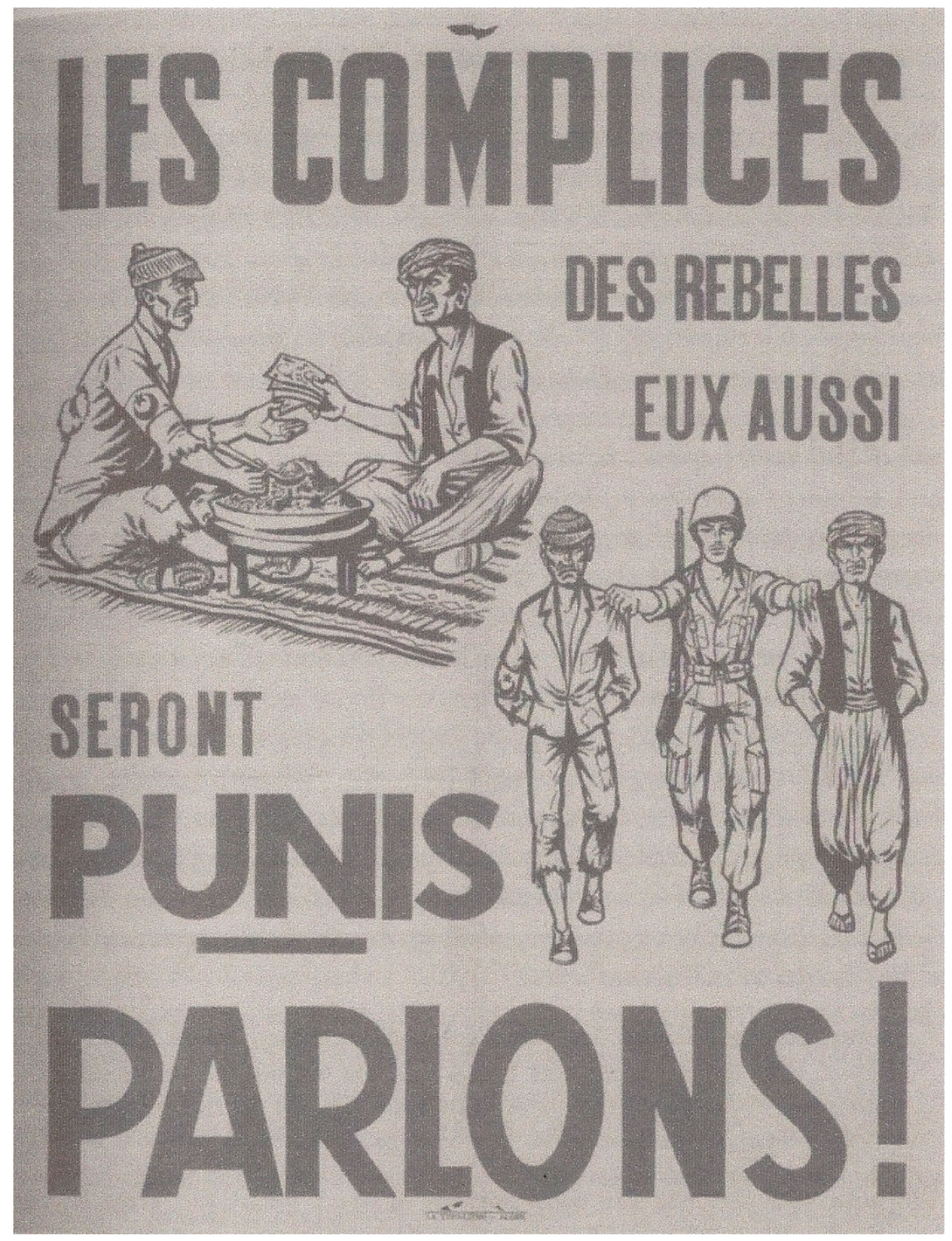

'The accomplices of the rebels they also will be punished: Talk!' 


\section{Selected Bibliography}

Alleg, Henri. The Algerian Memoirs. Translated by Gila Walker. London: Seagull, 2012.

Alleg, Henri. The Question. Translated by John Calder. Lincoln: University of Nebraska Press, 2006.

Aussaresses, Paul. The Battle of the Casbah. Translated by Robert L. Miller. New York: Enigma Books, 2006.

De Beauvoir, Simone, and Gisele Halimi. Djamila Boupacha: The Story of the Torture of a Young Algerian Girl which Shocked Liberal French Opinion. New York: Macmillan, 1962.

Evans, Martin. Algeria: France's Undeclared War. Oxford: Oxford University Press, 2012.

Horne, Alistair. A Savage War of Peace. New York: The Viking Press, 1978.

Lazreg, Marnia. Torture and the Twilight of Empire: From Algiers to Baghdad. Princeton: Princeton University Press, 2008.

Le Sueur, James D. Torture and the Decolonization of French Algeria: Colonial and Post-Colonial Incarceration, ed. Graeme Harper (London: Continuum International publishing, 2002). 